\title{
IMPLEMENTASI METODE CERTAINTY FACTORS UNTUK MENDIAGNOSA PENYAKIT PADA UNGGAS PEDAGING
}

\author{
Devi Saputri ${ }^{1}$, Intan Nur Farida ${ }^{2}$, Umi Mahdiyah ${ }^{3}$, Ahmad Bagus Setiawan $^{4}$ \\ Teknik Informatika, Fakultas Teknik, Universitas Nusantara PGRI Kediri \\ Jl. KH Ahmad Dahlan No. 76 Kediri \\ E-mail:*1'devisaputri1906@gmail.com,*2in.nfarida@gmail.com, ${ }^{3}$ umimahdiyah@gmail.com, \\ 4ahmadbagus@unpkediri.ac.id
}

\begin{abstract}
ABSTRAKS
Industri perunggasan di Indonesia menunjukkan bahwa unggas memiliki peranan yang cukup penting dalam meningkatkan perekonomian masyarakat. Populasi unggas dari tahun ke tahun mengalami peningkatan karena jumlah penduduk yang semakin banyak menyebabkan kebutuhan protein hewani juga bertambah. Meskipun produktifitas mengalami peningkatan tetapi peternak masih mengalami kendala ketika unggas terserang penyakit. Kurangnya pengetahuan peternak terhadap penyakit yang muncul dan timbulnya gejala yang dialami tanpa mengetahui penyakit serta solusinya mengakibatkan banyaknya unggas mengalami kematian. Penelitian ini menggunakan konsep sistem pakar untuk mendiagnosa penyakit yang muncul sesuai gejala yang dialami pada unggas pedaging khususnya ayam dan bebek. Metode yang digunakan adalah certainty factors dengan mengekspresikan tingkat keyakinan seorang pakar terhadap suatu masalah yang sedang terjadi. Sistem ini dapat membantu peternak dalam mengidentifikasi penyakit pada unggas pedaging sesuai gejala yang ada dan memberikan solusi penanganannya. Berdasarkan pengujian pada 30 data yang dilakukan terhadap sistem diperoleh tingkat akurasi sebesar 96,66\% .
\end{abstract}

Kata Kunci: certainty factors, sistem pakar, unggas pedaging.

\begin{abstract}
The poultry industry in Indonesia shows that poultry has an important role in improving the community's economy. The poultry population from year to year has increased because the population is increasing, causing the need for animal protein to also increase. Even though productivity has increased, breeders still experience problems when poultry catches disease. Lack of farmers' knowledge of the diseases that arise and the emergence of symptoms without knowing the disease and its solutions have resulted in the death of many birds. This study uses the concept of an expert system to diagnose diseases that arise according to the symptoms experienced in broilers, especially chickens and ducks. The method used is certainty factors by expressing the level of confidence of an expert on a problem that is happening. This system can help farmers identify diseases in broilers according to existing symptoms and provide solutions for handling them. Based on testing on 30 data carried out on the system, the accuracy rate is $96.66 \%$.
\end{abstract}

Keywords: certainty factors, expert systems, broilers.

\section{PENDAHULUAN}

\subsection{Latar Belakang}

Unggas (poultry) adalah jenis ternak bersayap dari kelas Aves yang telah didomestikasikan dan cara hidupnya diatur oleh manusia dengan tujuan untuk memberikan nilai ekonomis dalam bentuk barang (daging atau telur) dan jasa (pendapatan). Hasil pokok dari unggas adalah daging dan telur, sementara hasil sampingan berupa bulu dan kotoran serta kesenangan (ornamental) sebagai hasil khusus. Peranan unggas dari tahun ke tahun semakin meningkat. Hal ini dapat dimengerti karena unggas mampu memberikan kontribusi yang tinggi terhadap pembangunan bidang pertanian, khususnya sub bidang peternakan (Yuwanita, 2004).

Dalam industri perunggasan di Indonesia, unggas memiliki peranan yang cukup penting dalam meningkatkan perekonomian masyarakat. Populasi unggas dari tahun ke tahun mengalami sebuah peningkatan, peningkatan ini tidak terlepas karena jumlah penduduk yang semakin banyak dan pentingnya protein hewani terhadap tubuh manusia. Meskipun produktifitas mengalami peningkatan tetapi peternak masih mengalami kendala ketika unggas ternaknya terserang oleh penyakit. Kurangnya pengetahuan peternak terhadap penyakit yang muncul dan timbulnya gejala yang dialami tanpa mengetahui penyakit serta solusinya mengakibatkan banyaknya unggas mengalami kematian. Untuk mengatasi masalah tersebut dapat menggunakan bantuan sistem informasi yakni dengan menggunakan sistem pakar.

Sistem pakar (expert system) adalah sistem yang berusaha mengadopsi pengetahuan manusia ke komputer, agar komputer dapat menyelesaikan masalah seperti yang biasa dilakukan oleh para ahli, dan sistem pakar yang baik dirancang agar dapat 
menyelesaikan suatu permasalahan tertentu dengan meniru kerja dari para ahli (Kuwumadewi, 2003).

Rumusan permasalahan pada penelitian ini yaitu bagaimana mengimplementasikan metode certainty factors untuk mendiagnosa penyakit pada unggas pedaging. Sedangkan tujuan penelitian ini adalah untuk mengimplementasikan metode certainty factors dalam mendiagnosa penyakit pada unggas pedaging dengan menggunakan konsep sistem pakar.

Pembuatan sistem pakar dalam penelitian ini adalah untuk membantu peternak dalam mengidentifikasi penyakit pada unggas pedaging dengan gejala yang ada dan memberikan solusi penanganannya. Sistem ini dapat menjadi tahap keputusan pertama peternak untuk mengetahui jenis penyakit yang diderita sebelum dilakukan tahap berikutnya yaitu dengan melalui uji laboratorium untuk mengambil hasil kesimpulan.

Penelitian sebelumnya tentang penerapan metode certainty factors pada sistem pakar diagnosa penyakit ayam yang menghasilkan keluaran berupa kemungkinan penyakit ayam berdasarkan gejala yang dimasukkan pengguna kedalam aplikasi dan memberikan solusi pengobatannya (Yulianto, 2020).

Penelitian ini membahas tentang diagnosa penyakit unggas pedaging (ayam dan bebek) dengan menggunakan metode certainty factors. Sistem ini berbasis web menggunakan kode PHP dan database MySQL serta menerapkan metode certainty factors.

\section{METODOLOGI PENELITIAN}

Penelitian ini menerapkan metode certainty factors untuk memberikan solusi permasalahan dalam mendiagnosa penyakit pada unggas pedaging. Tahapan penelitian ini antara lain meliputi studi literatur, pengumpulan data, analisa sistem, perancangan sistem, implementasi dan pengujian.

\subsection{Studi Literatur}

\subsubsection{Penelitian Terdahulu}

Penelitian terdahulu pernah dilakukan yaitu implementasi metode certainty factor untuk mendiagnosa penyakit ayam broiler berupa layanan konsultasi kesehatan secara online (Syafitri, 2020). Penyelesaian untuk masalah mendiagnosa penyakit ayam juga dilakukan pada penelitian lainnya dengan menerapkan metode forward chaining (Hadi, 2016). Penelitian pada penyakit bebek khususnya flu burung pernah dilakukan dengan menerapkan metode certainty factor (Ramadhan, 2019). Selain itu terdapat penelitian yang menerapkan metode certainty factor untuk diagnosa penyakit pada manusia khususnya penyakit mata katarak (Girsang, 2019).

\subsubsection{Certainty Factor}

Certainty Factors (CFs) adalah suatu metode untuk mengakomodir pendapat seorang pakar yang tidak pasti pada saat seorang pakar tidak yakin pada kepastian suatu masalah dengan menyatakan ungkapan seperti "mungkin", "kemungkinan besar", "hampir pasti" dan lain-lain. Certainty Factors (CFs) mengungkapkan ukuran kepastian mengenai fakta atau aturan (Yulianto, 2020). Rumus Certainty Factors (CFs) didefinisikan sebagai berikut:

$\mathrm{CFs}[\mathrm{h}, \mathrm{e}]=\mathrm{MB}[\mathrm{h}, \mathrm{e}]-\mathrm{MD}[\mathrm{h}, \mathrm{e}]$.

Persamaan 1 merupakan faktor kepastian yang berasal dari selisih antara ukuran kepercayaan atau tingkat keyakinan terhadap hipotesis h, jika diberikan evidence e (antara 0 dan 1) dan ukuran ketidakpercayaan atau tingkat keyakinan t erhadap hipotesis $\mathrm{h}$, jika diberikan evidence e (antara 0 dan 1).

Terdapat dua cara untuk memperoleh tingkat keyakinan $(\mathrm{CF})$ pada aturan atau rule (Syafitri, 2020) yaitu:

a. Metode Net Belif yang diusulkan oleh E.H Shortliffe dan B.G Buchanan

$$
\begin{aligned}
& \mathrm{CF}(\text { rule })=\mathrm{MB}(\mathrm{H}, \mathrm{E})-\mathrm{MD}(\mathrm{H}, \mathrm{E}) \\
& \mathrm{MB}(\mathrm{H}, \mathrm{E}) \\
& =\mid \frac{\operatorname{Max}[\mathrm{P}(\mathrm{H} \mid \mathrm{E}) / \mathrm{P}(\mathrm{H})]-\mathrm{P}[\mathrm{H})}{\operatorname{Max}\left[\mathrm{I}_{1} \mathrm{O}\right]-\mathrm{P}(\mathrm{H})}
\end{aligned}
$$

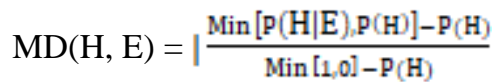

Penjelasan :

$\mathrm{CF}($ Rule $)=$ Faktor kepastian

$\mathrm{MB}(\mathrm{H}, \mathrm{E})=$ Measure of belief (ukuran kepercayaan) terhadap hipotesis $\mathrm{H}$, jika diberikan Evidence E (antara 0 dan 1).

$\mathrm{MD}(\mathrm{H}, \mathrm{E})=$ Measure of disbelief (ukuran ketidakpercayaan) terhadap Evidence $\mathrm{H}$, jika diberikan Evidance E (antara 0 dan 1).

$\mathrm{P}(\mathrm{H}) \quad=$ Probabilitas kebenaran Hipotesis $\mathrm{H}$.

$\mathrm{P}(\mathrm{H} \mid \mathrm{E}) \quad=$ Probabilitas bahwa $\mathrm{H}$ benar dengan fakta $E$.

b. Dengan cara mewawancarai pakar

Nilai CF(rule) didapat dari interprestasi "term" dari pakar yang diubah menjadi nilai $\mathrm{CF}$ tertentu sesuai tabel berikut:

Tabel 1. Interprestasi term menjadi nilai CF

\begin{tabular}{|l|c|}
\hline \multicolumn{1}{|c|}{ Uncertain term } & $C F$ \\
\hline Definetely not (pasti tidak) & 1.0 \\
\hline Almost certainly not (hampir pasti tidak) & 0.8 \\
\hline Probably not (kemungkinan besar tidak) & 0.6 \\
\hline Mayby not (mungkin tidah) & 0.4 \\
\hline Unknown (tidak tahu) & 0.2 to \\
& 0.2 \\
\hline Maybe (mungkin) & 0.4 \\
\hline Probably (kemungkinan benar) & 0.6 \\
\hline Almost certainly (hampir pasti) & 0.8 \\
\hline Definetely (pasti) & 1.0 \\
\hline
\end{tabular}

Pada tabel 1 menunjukkan kepastian dan ketidakpastian pada suatu data atau aturan, yang memiliki nilai tertinggi 1.0 (pasti) dan nilai terendah 
-1.0 (pasti tidak). Untuk nilai positif menunjukkan ukuran keyakinan dan nilai negatif menunjukkan ukuran ketidakyakinan terhadap suatu gejala. Jika belum terdapat nilai $\mathrm{CF}$ pada setiap gejala yang menimbulkan penyakit, maka menggunakan formula dasar untuk mendiagnosa penyakit (Girsang, 2019) yaitu:

1. Apabila terdapat aturan atau kaidah pada gejala tunggal (single permis rules) menggunakan persamaan 5:

CFgejala $=\mathrm{CF}[$ user $] * \mathrm{CF}[$ pakar $]$

2. Jika ada kaidah dengan kesimpulan yang sama (similiary concluded rules) atau lebih dari satu gejala, maka CF berikutnya dihitung menggunakan persamaan 6:

CFcom $=$ CFold + CFgejala $*(1-\mathrm{CFold}) \ldots \ldots \ldots .(6)$

3. Untuk menghitung presentase terhadap penyakit, digunakan persamaan 7:

CFpresentase $=$ CFcombine $* 100$

\subsection{Pengumpulan Data}

Pengumpulan dilaksanakan dengan melakukan tanya jawab secara langsung oleh narasumber terkait pada persoalan yang sedang terjadi dengan melakukan wawancara terhadap pakar (dokter hewan) dan peternak unggas di daerah kecamatan Tanjunganom, Nganjuk.

\subsection{Analisa Sistem}

Analisa sistem dilaksanakan dengan membuat spesifikasi kebutuhan sistem pakar penyakit unggas pedaging, khususnya ayam dan bebek.

Proses diagnosa ditunjukkan dalam serangkaian alur diagnosa. Serangkaian alur proses diagnosa penyakit unggas dilakukan oleh user. User login terlebih dahulu, setelah proses login selesai kemudian sistem akan menampilkan halaman diagnosa. Selanjutnya user dapat memilih kategori unggas yang akan didiagnosa (ayam atau bebek), berikutnya sistem akan menampilkan gejala sesuai dengan jenis unggas yang dipilih. Selanjutnya user dapat memilih gejala yang terjadi pada hewan ternaknya, kemudian sistem akan melakukan perhitungan menggunakan metode certainty factors. Sistem memberikan output berupa hasil diagnosa penyakit yang diderita dan solusi penanganannya. Kemudian user dapat mencetak hasil diagnosa penyakit.

\subsection{Perancangan Sistem}

Perancangan sistem merupakan kegiatan membuat desain sesuai hasil spesifikasi kebutuhan sistem, misalkan berupa desain interface.

\subsection{Implementasi}

Kegiatan implementasi sistem meliputi pembuatan halaman website dengan framewok, memasukkan data penyakit, data gejala dan data solusi ke dalam database MySQL. Selanjutnya alur program diintegrasikan dengan kode PHP serta melakukan uji coba sederhana yang menunjukkan bahwa hasil analisa secara teoritis yang telah dilakukan telah benar sesuai yang diharapkan.

\subsection{Pengujian}

Pengujian dilakukan untuk mengetahui keefektifan sistem yaitu data gejala yang telah diinputkan dapat diproses oleh sistem, sehingga sistem dapat menampilkan output berupa jenis penyakit dan penanganan sesuai gejala tersebut. Terdapat beberapa data uji yang dimasukkan sistem untuk mengevaluasi bahwa metode certainty factors yang diusulkan mampu menjawab tujuan pembuatan sistem.

\section{HASIL DAN PEMBAHASAN}

\subsection{Pembentukan Data Aturan (Rule)}

Pembentukan data aturan (rule) digunakan untuk proses pencarian dalam mengidentifikasi penyakit. Terdapat 12 penyakit ayam dengan 40 gejala ayam (Hadi, 2016) dan 11 penyakit bebek dengan 24 gejala bebek (Setiawan, 2016). Tabel 2 dan tabel 3 menunjukkan data penyakit serta gejala pada ayam:

Tabel 2. Data penyakit ayam

\begin{tabular}{|c|c|c|}
\hline No. & $\begin{array}{c}\text { Kode } \\
\text { penyakit }\end{array}$ & Nama penyakit \\
\hline 1 & P001 & $\begin{array}{lll}\text { Berak } & \text { Kapur } & \text { (Pullorum } \\
\text { Disease) } & & \\
\end{array}$ \\
\hline 2 & P002 & Kolera Ayam (Fowl Cholera) \\
\hline 3 & $\mathrm{P} 003$ & Flu Burung (Avian Influenza) \\
\hline 4 & $\mathrm{P} 004$ & Tetelo (Newcastle Disease) \\
\hline 5 & $\mathrm{P} 005$ & Tipus Ayam (Fowl Typhoid) \\
\hline 6 & P006 & Berak Darah (Coccidosis) \\
\hline 7 & P007 & Gumboro (Gumboro Disease) \\
\hline 8 & P008 & $\begin{array}{l}\text { Salesma } \\
\text { Coryza) }\end{array}$ Ayam $\quad$ (Infectious \\
\hline 9 & P009 & $\begin{array}{l}\text { Batuk Ayam Menahun } \\
\text { (Infectious } \\
\text { Bronchitis) }\end{array}$ \\
\hline 10 & P010 & $\begin{array}{lll}\text { Busung } & \text { Ayam } & \text { (Lymphoid } \\
\text { Leukosis) } & & \\
\end{array}$ \\
\hline 11 & P011 & $\begin{array}{lcl}\text { Batuk Darah } & \text { (Infectious } \\
\text { Laryngotracheitis) } & \end{array}$ \\
\hline 12 & P012 & Mareks (Mareks Disease) \\
\hline
\end{tabular}

Tabel 3. Data gejala penyakit ayam

\begin{tabular}{|c|c|l|}
\hline No. & $\begin{array}{c}\text { Kode } \\
\text { gejala }\end{array}$ & \multicolumn{1}{c|}{ Nama gejala } \\
\hline 1 & G001 & Nafsu makan berkurang \\
\hline 2 & G002 & Nafas sesak \\
\hline 3 & G003 & Nafas ngorok \\
\hline 4 & G004 & Nafas cepat \\
\hline 5 & G005 & Bersin-bersin \\
\hline 6 & G006 & Batuk \\
\hline 7 & G007 & Badan Kurus \\
\hline 8 & G008 & Bulu kusam dan berkerut \\
\hline 9 & G009 & Diare \\
\hline 10 & G010 & Produksi telur menurun \\
\hline
\end{tabular}




\begin{tabular}{|c|c|c|}
\hline 11 & G011 & Terlihat ngantuk dan bulu berdiri \\
\hline 12 & G012 & Kedinginan \\
\hline 13 & G013 & Tampak lesu \\
\hline 14 & G014 & Mencret kehijau-hijauan \\
\hline 15 & G015 & Mencret keputih-putihan \\
\hline 16 & G016 & Mencret bercampur darah \\
\hline 17 & G017 & Banyak Minum \\
\hline 18 & G018 & Muka pucat \\
\hline 19 & G019 & Nampak menbiru \\
\hline 20 & G020 & Sempoyongan \\
\hline 21 & G021 & Jengger membengkak merah \\
\hline 22 & G022 & Jengger pucat \\
\hline 23 & G023 & Kaki bengkak \\
\hline 24 & G024 & Kaki meradang/lumpuh \\
\hline 25 & G025 & Kaki pincang \\
\hline 26 & G026 & Kelopak mata kemerahan \\
\hline 27 & G027 & Keluar cairan berbusa dari mata \\
\hline 28 & G028 & $\begin{array}{l}\text { Keluar cairan dari mata dan } \\
\text { hidung }\end{array}$ \\
\hline 29 & G029 & Keluar nanah dari mata dan bau \\
\hline 30 & G030 & Kepala bengkak \\
\hline 31 & G031 & Kepala terputar \\
\hline 32 & G032 & Mata berair \\
\hline 33 & G033 & $\begin{array}{l}\text { Pembengkakan dari sinus dan } \\
\text { mata }\end{array}$ \\
\hline 35 & G035 & Sayap menggantung \\
\hline 36 & G036 & $\begin{array}{l}\text { Terdapat kotoran putih menempel } \\
\text { disekitar anus }\end{array}$ \\
\hline 37 & G037 & $\begin{array}{l}\text { Terdapat lendir bercampur darah } \\
\text { pada rongga mulut }\end{array}$ \\
\hline 38 & G038 & $\begin{array}{l}\text { Tidur paruhnya diletakkan di } \\
\text { lantai }\end{array}$ \\
\hline 39 & G039 & $\begin{array}{l}\text { Duduk dengan sikap } \\
\text { membungkuk }\end{array}$ \\
\hline 40 & G040 & Mati secara mendadak \\
\hline
\end{tabular}

Masing-masing gejala peyakit akan diberikan kode gejala secara otomatis, kode gejala penyakit ayam kemudian kode gejala penyakit bebek dengan kode gejala mulai dari G001 sampai selanjutnya hingga smua penyakit memiliki kode gejala.

Tabel 4. Data penyakit bebek

\begin{tabular}{|c|c|l|}
\hline No. & Kode penyakit & \multicolumn{1}{|c|}{ Nama penyakit } \\
\hline 1 & $\mathrm{P} 013$ & Kolera \\
\hline 2 & $\mathrm{P} 014$ & Botulismus \\
\hline 3 & $\mathrm{P} 015$ & Brooder Pneumonia \\
\hline 4 & $\mathrm{P} 016$ & Salmonellosis \\
\hline 5 & $\mathrm{P} 017$ & Hepatitis \\
\hline 6 & $\mathrm{P} 018$ & Cacar (Fowl Pox) \\
\hline 7 & $\mathrm{P} 019$ & Mata memutih (white eye) \\
\hline 8 & $\mathrm{P} 020$ & Tetelo \\
\hline 9 & $\mathrm{P} 021$ & Cacingan \\
\hline 10 & $\mathrm{P} 022$ & Coccidiosis \\
\hline 11 & $\mathrm{P} 023$ & Mycosis \\
\hline
\end{tabular}

Kode penyakit bebek pada penelitian ini merupakan kode lanjutan dari kode penyakit sebelumnya. Adapun data penyakit bebek ditunjukkan pada tabel 4 dan gejalanya ditunjukkan pada tabel 5 .

Tabel 5. Data gejala penyakit bebek

\begin{tabular}{|c|c|l|}
\hline No. & $\begin{array}{c}\text { Kode } \\
\text { gejala }\end{array}$ & \multicolumn{1}{|c|}{ Nama gejala } \\
\hline 1 & G041 & Sesak nafas \\
\hline 2 & G042 & Sempoyongan \\
\hline 3 & G043 & Gangguan sendi \\
\hline 4 & G044 & Lesu \\
\hline 5 & G045 & Bulu kusut \\
\hline 6 & G046 & Sayap terkulai \\
\hline 7 & G047 & Lumpuh \\
\hline 8 & G048 & Kotoran berwarna hijau \\
\hline 9 & G049 & Leher lunglai \\
\hline 10 & G050 & Mata berair \\
\hline 11 & G051 & Kepala bengkak \\
\hline 12 & G052 & Lubang hidung tertutup kotoran \\
\hline 13 & G053 & Kotoran encer warna putih \\
\hline 14 & G054 & Kejang \\
\hline 15 & G055 & $\begin{array}{l}\text { Darah jumlah berlebih pada } \\
\text { paruh }\end{array}$ \\
\hline 16 & G056 & Benjolan pada kaki \\
\hline 17 & G057 & Keluar ciairan putih pada paruh \\
\hline 18 & G058 & Nafsu makan berkurang \\
\hline 19 & G059 & Kotoran berdarah \\
\hline 20 & G060 & Badan kurus \\
\hline 21 & G061 & Mencret \\
\hline 22 & G062 & Warna bulu kusam \\
\hline 23 & G063 & Benjolan pada kepala \\
\hline 24 & G064 & Benjolan pada tubuh \\
\hline & & \\
\hline
\end{tabular}

Pada tabel 6 dan tabel 7 menunjukkan data aturan (rule) yang digunakan untuk menghubungkan antara data penyakit dengan data gejala. Data aturan ini berfungsi untuk mencari penyakit yang diderita oleh unggas ayam dan bebek.

Tabel 6. Data aturan (rule) pada ayam

\begin{tabular}{|c|c|c|}
\hline No. & $\begin{array}{c}\text { Kode } \\
\text { penyakit }\end{array}$ & \multicolumn{1}{c|}{ Kode gejala } \\
\hline 1 & P001 & $\begin{array}{l}\text { G001 and G002 and G004 and } \\
\text { G007 and G008 and G009 and } \\
\text { G010 and G012 and G015 and } \\
\text { G023 and G036 }\end{array}$ \\
\hline 2 & & $\begin{array}{l}\text { G001 and G002 and G003 and } \\
\text { G006 and G008 and G009 and } \\
\text { G010 and G011 and G013 and } \\
\text { G014 and G017 and G021 and } \\
\text { G024 and G028 }\end{array}$ \\
\hline 3 & P002 & $\begin{array}{l}\text { G001 and G002 and G003 and } \\
\text { G005 and G006 and G009 and } \\
\text { G010 and G019 and G027 and } \\
\text { G030 and G040 }\end{array}$ \\
\hline 4 & P003 & $\begin{array}{l}\text { G001 and G002 and G003 and } \\
\text { G005 and G006 and G010 and }\end{array}$ \\
\hline
\end{tabular}




\begin{tabular}{|c|c|c|}
\hline & & $\begin{array}{l}\text { G013 and G014 and G020 and } \\
\text { G031 }\end{array}$ \\
\hline 5 & P005 & $\begin{array}{l}\text { G001 and G007 and G008 and } \\
\text { G009 and G011 and G013 and } \\
\text { G014 and G022 }\end{array}$ \\
\hline 6 & P006 & $\begin{array}{l}\text { G001 and G007 and G008 and } \\
\text { G010 and G016 and G018 }\end{array}$ \\
\hline 7 & P007 & $\begin{array}{l}\text { G001 and G008 and G013 and } \\
\text { G015 and G038 and G039 }\end{array}$ \\
\hline 8 & P008 & $\begin{array}{l}\text { G001 and G005 and G009 and } \\
\text { G010 and G026 and G029 and } \\
\text { G033 }\end{array}$ \\
\hline 9 & P009 & $\begin{array}{l}\text { G001 and G003 and G005 and } \\
\text { G006 and G009 and G010 and } \\
\text { G011 and G012 and G013 and } \\
\text { G019 }\end{array}$ \\
\hline 10 & P010 & $\begin{array}{l}\text { G001 and G002 and G007 and } \\
\text { G008 and G034 }\end{array}$ \\
\hline 11 & P011 & $\begin{array}{l}\text { G001 and G003 and G005 and } \\
\text { G006 and G032 and G037 }\end{array}$ \\
\hline 12 & P012 & $\begin{array}{l}\text { G001 and G004 and G007 and } \\
\text { G018 and G020 and G025 and } \\
\text { G035 }\end{array}$ \\
\hline
\end{tabular}

Tabel 7. Data aturan (rule) pada bebek

\begin{tabular}{|c|c|l|}
\hline No. & $\begin{array}{c}\text { Kode } \\
\text { penyakit }\end{array}$ & \multicolumn{1}{c|}{ Kode gejala } \\
\hline 1 & P013 & G041 and G042 and G043 \\
\hline 2 & P014 & $\begin{array}{l}\text { G041 and G044 and G045 and } \\
\text { G046 and G047 and G048 and } \\
\text { G049 }\end{array}$ \\
\hline 3 & P015 & G041 and G050 and G051 \\
\hline 4 & P016 & $\begin{array}{l}\text { G041 and G046 and G052 and } \\
\text { G053 }\end{array}$ \\
\hline 5 & P017 & G045 and G054 and G055 \\
\hline 6 & P018 & G046 and G063 and G064 \\
\hline 7 & P019 & $\begin{array}{l}\text { G041 and G047 and G054 and } \\
\text { G057 }\end{array}$ \\
\hline 8 & P020 & $\begin{array}{l}\text { G041 and G044 and G046 and } \\
\text { G047 and G048 and G049 and } \\
\text { G054 and G058 }\end{array}$ \\
\hline 9 & P021 & $\begin{array}{l}\text { G044 and G058 and G059 and } \\
\text { G060 and G061 and G062 }\end{array}$ \\
\hline 10 & P022 & G047 and G058 and G060 \\
\hline 11 & P023 & G044 and G058 and G060 \\
\hline
\end{tabular}

\subsection{Tampilan Sistem}

Penelitian ini menghasilkan aplikasi yang dapat mendiagnosa penyakit pada ungags pedaging yaitu ayam dan bebek dengan menerapkan metode certainty factors. Gambar 1 menunjukkan halaman awal ketika user masuk ke dalam sistem. Didalam halaman ini terdapat menu diagnosa, riwayat diagnosa, dan artikel (berisi informasi tentang penyakit ayam dan bebek).

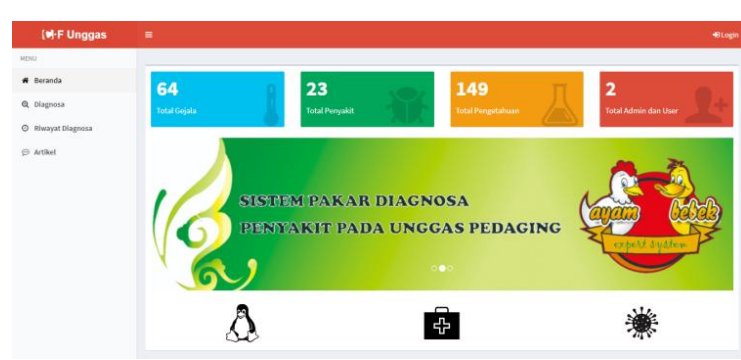

Gambar 1. Halaman beranda

Halaman login user berfungsi untuk mengkonfirmasi user jika sudah terdaftar dalam aplikasi. Pada halaman ini user memasukkan username dan password, kemudian sistem akan melakukan validasi data yang telah dimasukkan dengan data yang sudah ada dalam database sistem. Halaman login user ditunjukkan pada gambar 2.

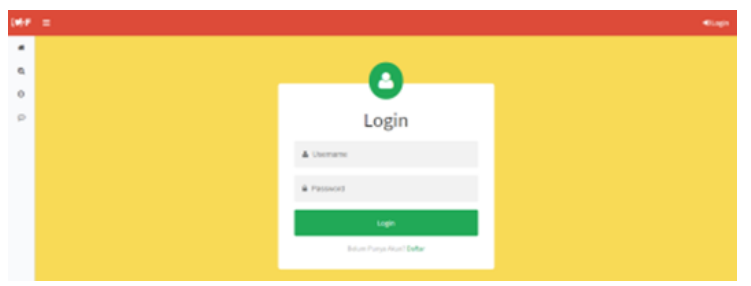

Gambar 2. Halaman login

Halaman diagnosa ditunjukkan pada gambar 3 merupakan halaman untuk melakukan diagnosa penyakit, user memilih jenis unggas terlebih dahulu (ayam atau bebek), kemudian memilih gejala yang terjadi pada unggas, klik tombol (+) untuk proses diagnosa, setelah selesai maka muncul hasil diagnosa penyakit.

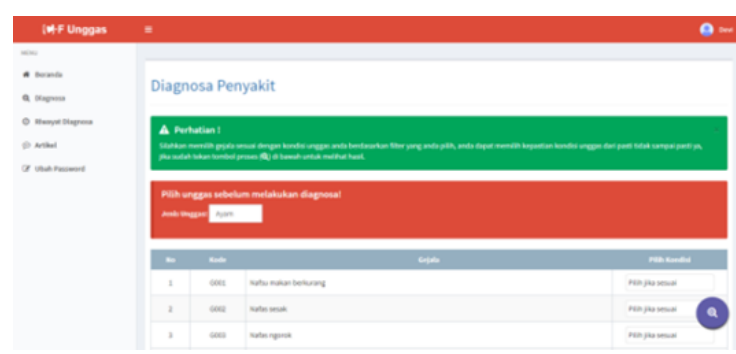

Gambar 3. Halaman diagnosa

Hasil diagnosa penyakit tampak pada gambar 4 yaitu informasi jenis penyakit yang diderita dan presentase dari nilai penyakit. Halaman ini menampilkan nomor, kode gejala, gejala yang dialami (keluhan), pilihan user, nilai certainty factors baik dari user maupun pakar. Selain itu ada jenis penyakit dan presentase nilai,simulasi perhitungan detail penyakit, saran/solusi dan kemungkinan penyakit lain. 


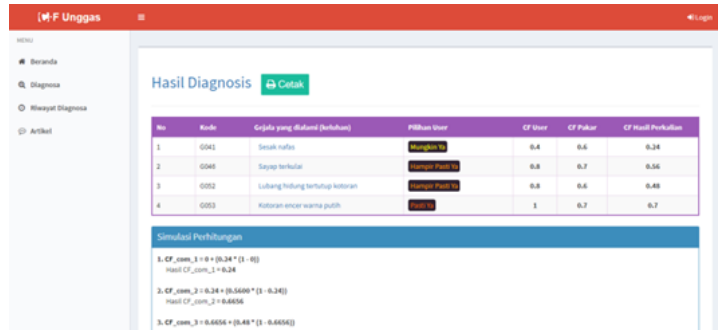

Gambar 4. Halaman hasil diagnosa

Halaman riwayat diagnosa sebagaimana ditunjukkan gambar 5 merupakan halaman untuk melihat riwayat diagnosa penyakit yang pernah dilakukan oleh user yang sudah disimpan dalam database. Terdapat pilihan filter untuk memfilter data riwayat diagnosa berdasarkan unggas ayam atau bebek. Selain itu ada tombol detail untuk melihat hasil diagnosa yang sudah dilakukan user.

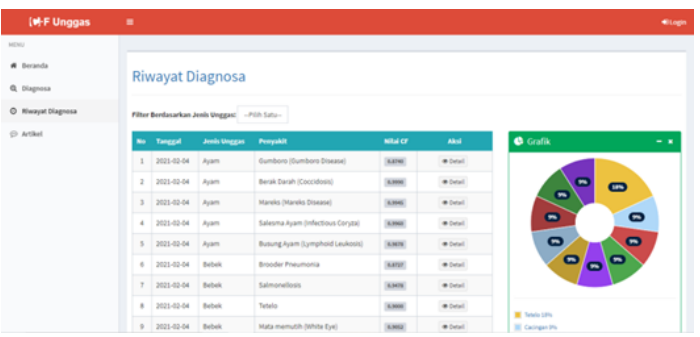

Gambar 5. Halaman riwayat diagnosa

Halaman artikel digunakan untuk menampilkan data tentang informasi penyakit yang ada pada sistem. Halaman ini dapat menampilkan pilihan detail (yang berisi tentang penyakit, penyebab penyakit, gejala penyakit, cara penularan,) dan saran (yang berisi tentang pencegahan dan pengendalian). Halaman artikel ditunjukkan pada gambar 6 .

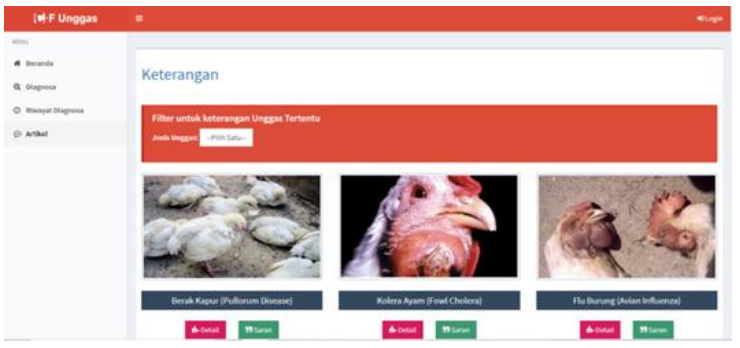

Gambar 6. Halaman artikel

\subsection{Pembahasan}

Pengujian sistem pakar diagnosa penyakit unggas pedaging menggunakan metode certainty factors bertujuan untuk menilai kinerja sistem yang sedang dibuat. Pengujian ini dilakukan dengan mengambil sampel dari data diagnosa yang dilakukan oleh user. Berikut analisa simulasi perhitungan sederhana metode certainty factors serta implementasi sistem.

Analisa perhitungan ini merupakan salah satu proses untuk menentukan prosentase hasil dari diagnosa penyakit. Analisa perhitungan pada pengujian ini menggunakan aturan diagnosa pada salah satu penyakit bebek yaitu Salmonellosis. Ada beberapa tahapan perhitungan sebagai berikut :

1. Pakar memberikan nilai $\mathrm{CF}$ untuk setiap gejala sesuai dengan aturan yang sudah dibuat, yaitu misalkan:

IF G0041 : Sesak nafas (nilai $\mathrm{CF}=0.6$ )

AND G046 : Sayap terkulai (nilai $\mathrm{CF}=0.7$ )

AND G052 : Lubang hidung tertutup kotoran (nilai $\mathrm{CF}=0.6$ )

AND G053 : Kotoran encer warna putih (nilai $\mathrm{CF}=0.7)$

THEN P011 Penyakit Salmonellosis.

Kemudian dilanjutkan penentuan nilai bobot dari user misalkan user diberikan pertanyaan dan menentukan jawaban sebagaimana disajikan pada tabel 8 .

Tabel 8. Pertanyaan dan jawaban user (nilai ef user)

\begin{tabular}{|l|l|l|l|}
\hline No & Pertanyaan & Jawaban & $\begin{array}{c}\text { Bobot } \\
\text { user }\end{array}$ \\
\hline 1 & $\begin{array}{l}\text { Apakah bebek } \\
\text { mengalami sesak } \\
\text { nafas? }\end{array}$ & Mungkin ya & 0.4 \\
\hline 2 & $\begin{array}{l}\text { Apakah bebek } \\
\text { mengalami sayap } \\
\text { terkulai t? }\end{array}$ & $\begin{array}{l}\text { Hampir pasti } \\
\text { ya }\end{array}$ & 0.8 \\
\hline 3 & $\begin{array}{l}\text { Apakah bebek } \\
\text { mengalami lubang } \\
\text { hidung tertutup } \\
\text { kotoran? }\end{array}$ & $\begin{array}{l}\text { Hampir pasti } \\
\text { ya }\end{array}$ & 0.8 \\
\hline 4 & $\begin{array}{l}\text { Apakah bebek } \\
\text { mengalami kotoran } \\
\text { encer warna putih? }\end{array}$ & Pasti ya & 1.0 \\
\hline
\end{tabular}

2. Kaidah-kaidah berikutnya dihitung nilai CFnya menggunakan rumus persamaan 5, yaitu:

$\mathrm{CF}$ gejala $=\mathrm{CF}[$ user $] * \mathrm{CF}$ [pakar]

Perhitungan $\mathrm{CF}$ gejala:

$$
\begin{array}{rr}
\mathrm{CF}[\mathrm{H}, \mathrm{E}] 1=\mathrm{CF}[\mathrm{H}] 1 & * \mathrm{CF}[\mathrm{E}] 1 \\
& =0.4 * 0.6 \\
& =0.24 \\
\mathrm{CF}[\mathrm{H}, \mathrm{E}] 2=\mathrm{CF}[\mathrm{H}] & 2 * \mathrm{CF}[\mathrm{E}] 2 \\
& =0.8 * 0.7 \\
& =0.56 \\
\mathrm{CF}[\mathrm{H}, \mathrm{E}] 3=\mathrm{CF}[\mathrm{H}] & 3 * \mathrm{CF}[\mathrm{E}] 3 \\
& =0.8 * 0.6 \\
& =0.48
\end{array}
$$

$$
\begin{aligned}
\mathrm{CF}[\mathrm{H}, \mathrm{E}] 3 & =\mathrm{CF}[\mathrm{H}] 4 * \mathrm{CF}[\mathrm{E}] 4 \\
& =0.7
\end{aligned}
$$

3. Menggabungkan nilai $\mathrm{CF}$ dari tiap-tiap kaidah dengan menggunakan persamaan 6 yaitu :

Cf com $=\mathrm{Cf}$ old $+\mathrm{CF}$ gejala*(1-CF old $).$ 
Perhitungan CF kombinasi:

CFcom $\mathrm{CF}[\mathrm{H}, \mathrm{E}] 1,2=\mathrm{CF}[\mathrm{H}, \mathrm{E}] 1+\mathrm{CF}[\mathrm{H}, \mathrm{E}] 2 *(1-$ $\mathrm{CF}[\mathrm{H}, \mathrm{E}] \mathrm{1})$

$$
\begin{aligned}
& =0.24+0.56 *(1-0.24) \\
& =0.24+0.4256 \\
& =0.6656 \text { old } 1
\end{aligned}
$$

$\mathrm{CF}$ com $\mathrm{CF}[\mathrm{H}, \mathrm{E}]$ old $2=\mathrm{CF}[\mathrm{H}, \mathrm{E}]$ old $+\mathrm{CF}[\mathrm{H}, \mathrm{E}]$ $3 *(1-\mathrm{CF}[\mathrm{H}, \mathrm{E}]$ old $)$

$$
\begin{aligned}
& =0.6656+0.48 *(1-0.6656) \\
& =0.6656+0.160512 \\
& =0.8261 \text { old } 3
\end{aligned}
$$

$\mathrm{CF}$ com $\mathrm{CF}[\mathrm{H}, \mathrm{E}]$ old $3=\mathrm{CF}[\mathrm{H}, \mathrm{E}]$ old $+\mathrm{CF}[\mathrm{H}, \mathrm{E}]$ $4 *(1-\mathrm{CF}[\mathrm{H}, \mathrm{E}]$ old $)$

$$
\begin{aligned}
& =0.8261+0.7 *(1-0.8261) \\
& =0.8261+0.12173 \\
& =0.9478 \text { old } 4
\end{aligned}
$$

4. Menentukan hasil perhitungan dengan menggunakan persamaan 7 yaitu:

$$
\text { CFpresentase }=\mathrm{CF} \text { combine } * 100
$$

Perhitungan CF presentase:

$$
\begin{aligned}
\mathrm{CF}[\mathrm{H}, \mathrm{E}] \text { old } 4 * 100 & =0.9478 * 100 \\
& =94.78 \%
\end{aligned}
$$

Sehingga dapat dikatakan bahwa perhitungan certainty factors diagnosa penyakit Salmonellosis pada bebek memiliki presentase tingkat keyakinan $94.78 \%$

Setelah analisa perhitungan sederhana selesai maka dilakukan dengan pengujian pada sistem untuk mengetahui kesesuaian hasil perhitungan manual dengan sistem dengan kesimpulan penyakit yang sama.

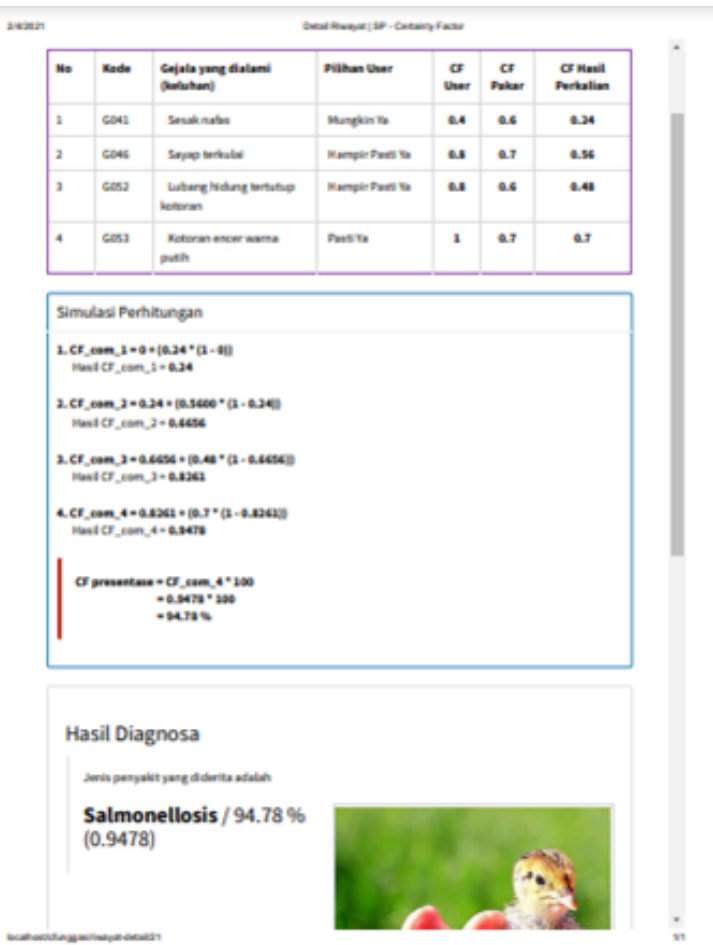

Gambar 7. Halaman data hasil diagnosa penyakit
Perhitungan menunjukkan hasil nilai presentase tingkat keyakinan penyakit sebesar $94.78 \%$ sedangkan pengujian sistem dengan data yang dimasukkan sesuai simulasi perhitungan dapat menampilkan hasil nilai perhitungan yang sama. Sebagaimana tampak pada gambar 7 .

Pengujian sistem juga dilakukan pada 30 sampel data uji yang terdiri dari 15 data uji penyakit ayam dan 15 data uji penyakit bebek. Data uji tersebut dimasukkan dalam sistem untuk diproses sehingga menghasilkan diagnosa penyakitnya. Pengujian setiap data uji yang terdiri dari beberapa gejala dihitung nilai certainty factor (cf) yang berasal dari user begitu juga dengan nilai cf dari pakar yang telah dimasukkan dalam sistem. Selanjutnya dihitung sesuai kaidah metode certainty factors. Dari 30 sampel data uji diketahui bahwa sebanyak 29 data uji menunjukkan kesesuaian hasil diagnosa penyakit baik pada sistem maupun dari pakar.

Setelah melakukan pengujian diagnosa sistem dengan diagnosa pakar (dokter hewan), maka dihitung nilai akurasinya dengan rumus persamaan 8 (Alfianto, 2019):

$$
\begin{aligned}
\text { Nilai akurasi } & =\frac{\sum \text { Akurasi }}{\sum U_{j i}} \times 100 \% \\
& =\frac{29}{30} \times 100 \% \\
& =96,66 \%
\end{aligned}
$$

Persamaan 8 menunjukkan nilai akurasi diperoleh dari perbandingan jumlah data memiliki akurasi yang tepat dengan jumlah kseluruhan data uji yang dikalikan dengan seratus persen.

Pengujian sistem dengan 30 data uji menunjukkan hasil akurasi sebanyak 96,66 \%. Hal ini menunjukkan bahwa aplikasi ini telah berhasil mendiagnosa penyakit unggas pedaging khususnya ayam dan bebek.

\section{KESIMPULAN}

Berdasarkan hasil dan pembahasan penelitian dapat disimpulkan bahwa penerapan metode certainty factors untuk mendiagnosa penyakit pada unggas pedaging berupa sistem pakar sesuai dengan kaidahnya telah berhasil dibuat. Sistem pakar ini memberikan output berupa jenis penyakit dan solusi penanganannya sesuai gejala yang dipilih (dialami oleh unggas) dengan perhitungan nilai prosentase penyakit menggunakan metode certainty factors. Tingkat keakuratan sistem terletak pada banyaknya aturan maupun knowledge base yang telah disimpan.

Adapun beberapa saran dan masukan yang berguna untuk pengembangan sistem yang lebih lanjut yaitu dapat dikembangkan dengan pilihan 
penyakit yang lebih banyak dan lebih meluas. Selain itu dapat ditambahkan metode lain yang lebih kuat dan akurat dalam proses penarikan kesimpulan. Serta dapat dikembangkan lebih lanjut dengan tambahan jenis hewan yang lain.

\section{PUSTAKA}

Alfianto, Agung. 2019. Sistem Pakar Diagnosa Penyakit Bebek Menggunakan Metode Forward Chaining Berbasis Android. Prosiding Seminar Nasional Fakultas Teknik UMAHA. (Online), (https://ejournal.umaha.ac.id/index.php/teknik/article/vie w/560, diakses 1 November 2020). Vol 1. Fakultas Teknik Universitas Maarif Hasyim (UMAHA) Sidoarjo.

Girsang, R. R., \& Fahmi, H. 2019. Sistem Pakar Mendiagnosa Penyakit Mata Katarak Dengan Metode Certainty Factor Berbasis Web. Jurnal Ilmu Komputer dan Teknologi Informasi. Vol.11, No. 1:27-31.

Hadi, Mohamad. M. Misdram. Ichsan. Ratih Fitri Aini. 2016. Perancangan Sistem Pakart Diagnosis Penyakit Ayam Dengan Metode Forward Chaining. Journal Jurnal Informatika Merdeka Pasuruan (JIMP). Vol 2, No 1.

Kusumadewi,S. 2003. Artificial intelligence. Yogyakarta: Graha Ilmu.

Ramadhan, Arief Gilang, Teguh Susyanto, Iwan Ady Prabowo. 2019. Sistem Diagnosa Penyakit Flu Burung pada bebek Menggunakan Metode Certainty Factor. Jurnal Tikomsin, Vol. 7 No.2.

Setiawan, Muhammad Galih, Fatah Yasin Al Irsyadi. 2016. Sistem Pakar untuk Mendiagnosa Penyakit pada bebek Berbasis Android. Skripsi. Universitas Muhammadiyah Surakarta. (Online), (http://eprints.ums.ac.id/45157/, diakses 9 November 2020).

Syafitri, Yuli. 2020. Implementasi Metode Certainty Factors Pada Sistem Pakar Diagnosis Penyakit Ayam Broiler. Jurnal Teknologi dan Informatika (JEDA). Vol.1, No. 1.

Yulianto, Donny., Idris., Wasiso, Ichsan. dan Kusrini. Implementasi Metode Certainty Factors Pada Sistem Pakar Diagnosis Penyakit Ayam Berbasis Web. 2020. Journal of Computer, Information System, \& Technology. Vol 3, No 1:16-23.

Yuwanta, Tri. 2004. Dasar Ternak Unggas. Yogyakarta: Penerbit Kanisius. 